\title{
Poetry in Teaching Grammar to the Advanced Users of Polish as a FL
}

\begin{abstract}
The article offers an insight into problematic issues the advanced learners of Polish as a FL cope with in terms of grammar in speaking and writing. It opens with a brief insight into teaching literature, poetry including, in a FL classroom. What follows includes types of poems and their potential to be used in the teaching context, mainly when teaching grammar. Having presented the scope of linguistic problems experienced by the users of Polish as a FL, the type and frequency of grammatical problems are discussed. Polish grammar-based issues the foreigners struggle with constituted the main area of the research conducted among 146 students of the Polish Language Course attending the School of Polish Language and Culture at the University of Silesia in Katowice, Poland. The findings come from oral and written assignments produced by the sample in question, and, most frequently, reflect grammatical mistakes that are persistent and difficult to eliminate from the linguistic repertoire. Given that, ways of using poetry as a means of a "grammar refresher" are suggested. These include a few examples of activities based on poems to be used when trying to overcome particular linguistic difficulties, together with implications for teachers raising students' language awareness and developing reflection on language per se.
\end{abstract}

Keywords: poetry, poems, grammar, grammar problems

In trying to show the language-literature and/or literature-language interplay, it is enough to reach any type of a literary genre. How these two coexist is best exemplified in a language and literature syllabus, but can also be a part of a general language course building on both linguistic and literary experiences aiding reflection, lengthening the span of attention and increasing learners' self-awareness. 


\section{Teaching Literature in a FL Classroom}

Undeniably, it is the language-based approach that is the most common approach to literature in the FL classroom. Following Carter and Long (1991), the exposure to literature can increase learners' vocabulary and linguistic structures, as well as a more creative aspect of the language consisting in metaphor, symbolism and imagery. A wide range of techniques commonly used with literary texts in a FL environment include close testing, matching synonyms, rephrasing, and jumbled lines, to name a few, and serve certain linguistic goals. It is most often to think about the meaning of the text. By approaching the text in this deconstructionist way and breaking it down into a series of its parts, the learners are given a chance to focus more on grammar structures. Following Hanauer (2001), what the classroom participants notice in this way involves the form (over $90 \%$ of learners), with $84 \%$ of unusual usage and only $9.87 \%$ paying attention to literary meaning.

The very numbers of noticing differ when it comes to the Personal Growth Model and its emotion-based nature. Here, the learners are encouraged to express personal opinions on a text, and relate any intellectual or emotional response to their own experiences. This technique follows the commonly held theory of reading which lays emphasis on the interaction of the reader with the text (Cadorath \& Harris, 1998).

In this regard poetry seems to be dominating over prose, and sounds very attractive for its readers as it is well-known for completeness and brevity of the text, and the encapsulation of the powerful thought or emotion. Though, the choice of the texts needs great care. A linguistically complex poem with new structures and sophisticated vocabulary is likely to be inaccessible to many FL learners, and result in a "switching off" rather than a desired effect, that is, emotional engagement in the text. The same seems to be true of poems requiring background knowledge of the social or historical milieu, and/or based on some factual information to be introduced beforehand by the teacher. Yet, even such difficult texts can be successful when provide direction for learners to construct meaning from their own experience.

\section{Poetry in a FL Classroom}

Following Szczęśniak (2009) poetry in teaching a FL is generally treated as an innovative potential aimed at developing students' linguistic and cognitive competences. In the former case, a well-prepared material, in the form of a text, is to influence lexis, grammar, and morphology, as well as become the 
basis of enhancing students' listening, reading, speaking and writing skills. The latter, on the other hand, giving social, cultural, and historical background, allows for acting, thinking, and feeling in a FL, including openness to other languages, cultures, and communities. Kozłowski (1991) goes even further and compares using poetry in a classroom to a multidimensional experience and a powerful effect on learners' literary, emotional, creative, aesthetic or critical competences, to name a few.

The more "attractive" the poem, the bigger influence on its receivers can be observed. What constitutes this text attractiveness is elaborated on by Burzyńska and Markowski (2006), according to whom it is composed of directiveness, clarity, or, paradoxically, the lack of both, as well as thought-provoking and innovative ideas, or a metaphorical nature of the language itself.

More specifically, it is distinctive features of poetic texts, such as for example rhythms, rhymes, onomatopoeic expressions, assonances, and alliterations that enrich the way the message is conveyed and the language in general is portrayed at the same time.

Working on a poetic text, as Szczęśniak (2009) has it, can start from just underlining given words, for example, vowels or consonants to pay learners' attention to word spelling. Looking for prefixes or suffixes, diminutives and/ or augmentatives, analogically, is to rise students' awareness of word formation and morphology. In the same vein, when asked to concentrate on certain parts of speech, such as verbs, nouns or adjectives and adverbs, the learners may develop their understanding of word order, as well as how these co-exist and form a larger unit referred to as a sentence structure.

The next step can be to read a poem and work on substituting given words or phrases, transforming parts and/or whole sentences, as well as coming up with new units. Practically, it may cover practicing plurals/singulars, inflections, tenses, and so on. And, finally, the students may be asked to reflect on word or sentence relations, ponder over their double/metaphorical meaning, as well as go for writing their own lines according to suggested patterns, or just get involved into free writing as such. Being so diversified, poetry seems to be a part of not only a very interesting text-based task to implement during regular classes, but also a series of remedy classes when something goes wrong.

\section{Types of Poems}

Taking all the above-mentioned into account, it is worth emphasizing that different poems serve different purposes, and can be used differently to promote language acquisition. The most common poem forms are picture poems and pattern poems. 


\section{Picture Poems}

According to Finch (2003), picture poems offer a visual perspective on the arrangement of words, and are, therefore, an effective means of encouraging learners to interact with the target vocabulary (Table 1).

Table 1.

An example of a picture poem (adapted from Hadfield \& Hadfield, 1991, p. 9)

\begin{tabular}{|c|c|}
\hline $\begin{array}{c}\text { One, two, } \\
\text { thump thump, } \\
\text { my heart beats for you } \\
\text { across the room and we } \\
\text { come closer together } \\
\text { in the space } \\
\text { between } \\
\text { us }\end{array} \quad \begin{array}{c}\text { A } \\
\text { can be tall, } \\
\text { short, wide or thin, } \\
\text { with many rooms, or only } \\
\text { a few. It can be } \\
\text { home for all the } \\
\text { family or simply } \\
\text { me and my pets. }\end{array}$ \\
\hline
\end{tabular}

Here the poems look like the object they describe. The structure is the shape of the object, and task completion comes from arranging words to match that shape.

To name an example of a task in Polish, the students can be asked to come up with a word, for example noodles (as in Figure 1), and "draw" its shape:

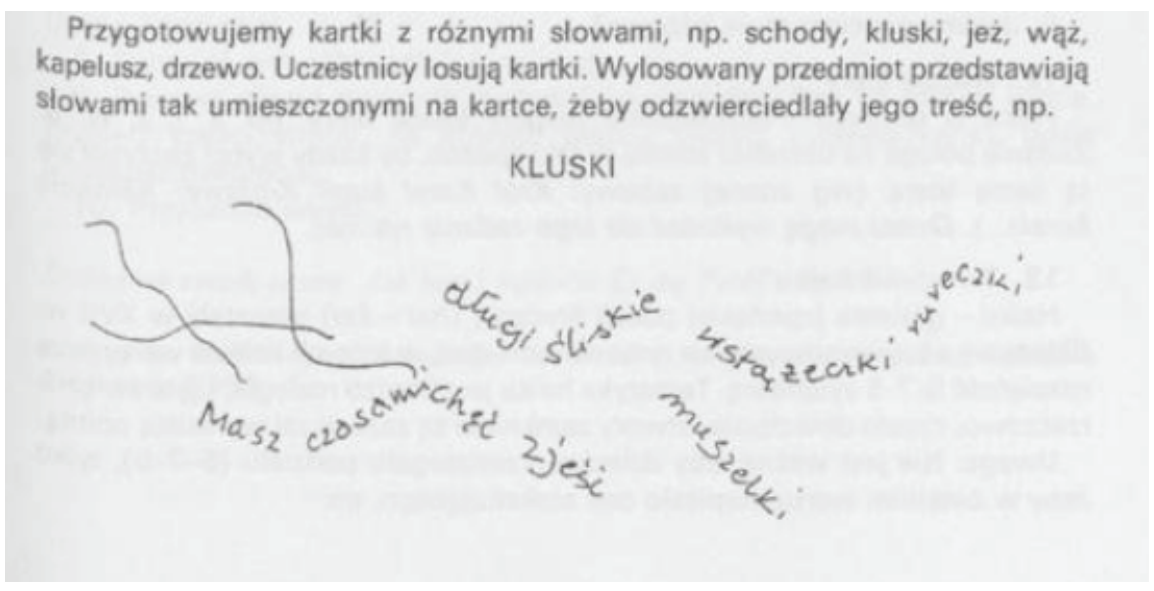

Figure 1. An example of a task in Polish: a picture poem (Mrożek, 1999, p. 125) 
Another type of a picture poem is the one in which the words outline the object being described. Again, these words can be sentences or collections of word-associations, and, thus, encourage the learners to interact and experiment with the language (Figure 2).
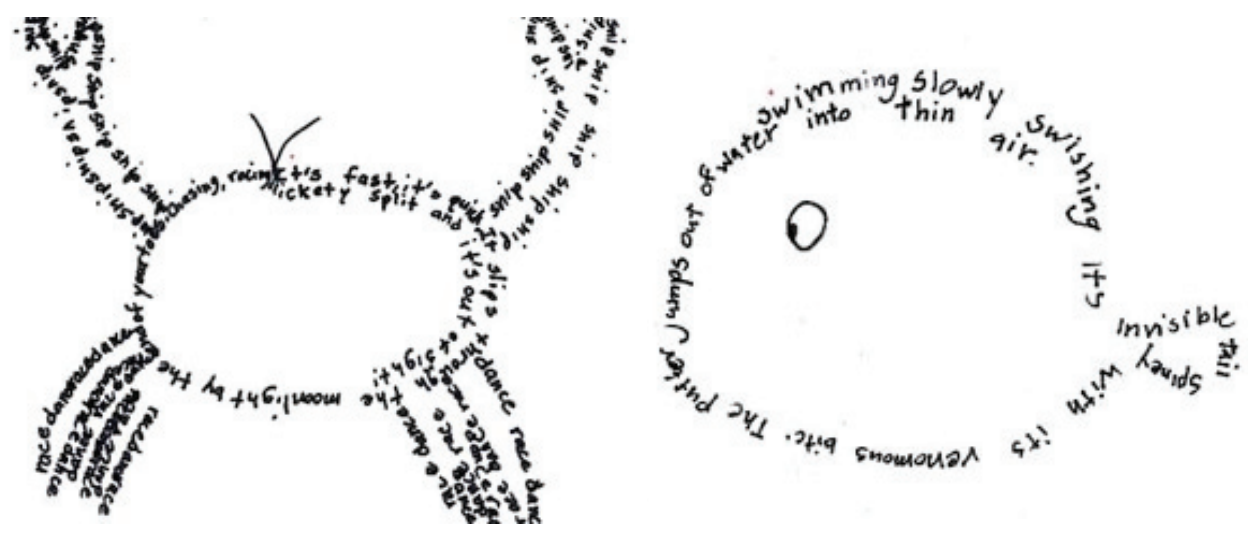

Figure 2. An example of a picture poem (adapted from Hadfield \& Hadfield, 1997, p. 16).

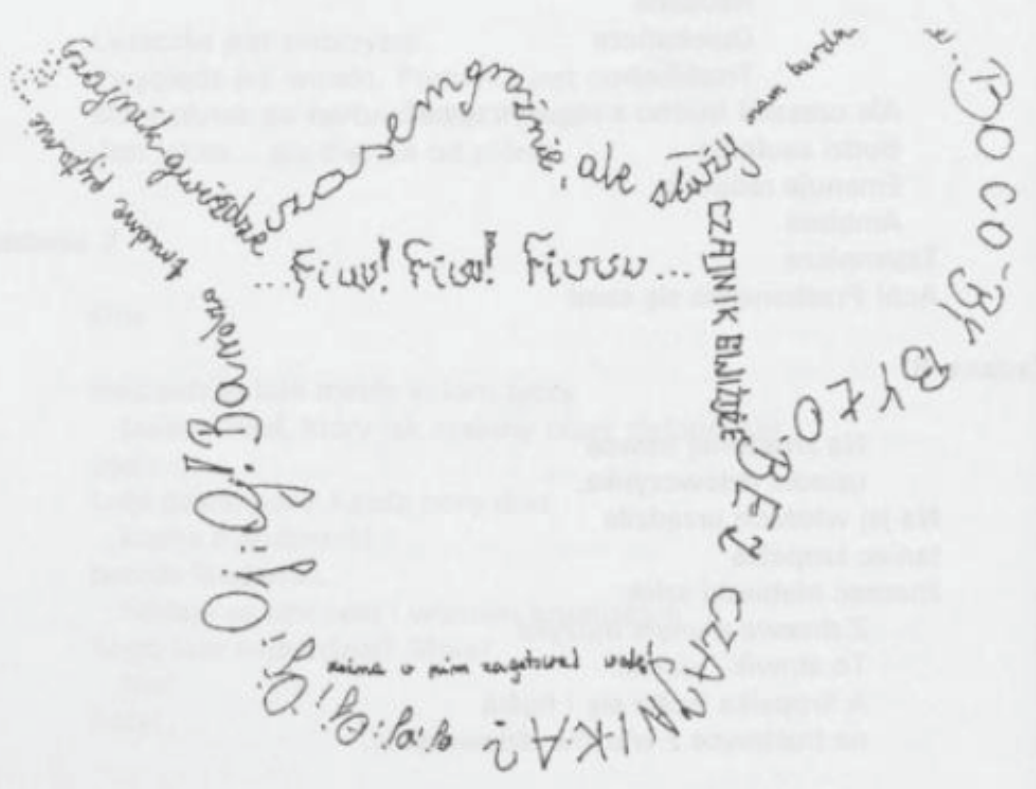

Figure 3. An example of a calligram poem in Polish (Mrożek, 1999, p. 132) 
Mrożek (1999) refers to the text visually arranged in a way that it forms contours associated with the text's content as a calligram poem. Practically speaking, it means that in order to create it the students may be asked to think of a given word, and present the line that appears to bound a given object, as in Figure 3.

\section{Pattern Poems}

Pattern poems, on the other hand, are believed to be especially successful in the FL classroom as they can be adopted to teaching grammar and sentence structure. Following Finch (2003), patterns in such poems usually consist of grammatical items (adjectives, adverbs, verbs, etc.,) metrical frameworks, phrases, or sentence structures, though they can also include acronyms:

Table 2

An example of a pattern poem (adapted from Holmes \& Moulton, 2001, p. 15)

\begin{tabular}{|l|l|l|}
\hline Furry face & Funny & Few people are \\
Red hair & Real & Real friends \\
Intelligent eyes & Interesting & In my life. I \\
Ears that hear everything & Enjoyable & Enjoy seeing true, not \\
Nose that sniffs & Nice & New friends every \\
Dog of my dreams & Delightful & Day \\
\hline
\end{tabular}

The very example presents an acrostic poem based on the word friend. The central acronym uses single word-association to describe the concept of friend, while the acronym to its left uses an adj + noun structure. The third acronym in this figure constructs two complete sentences, in which the required letters appear at the front of every three or four words. To give an example of a Polishcontext pattern poetry, it is worth looking at acronyms mentioned before or alphabetical sequencing giving rise to a number of texts and tasks for students suggested by Mrożek (1999):

Uczestnicy decydują się, na jaki temat chcieliby napisać wiersz - np. „Jesień".

Osoba prowadząca wypisuje na tablicy, w słupku, kolejne litery alfabetu występujące po ..J" np.

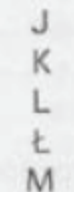

Figure 4. An example of a task for students in Polish (Mrożek, 1999, p. 123) 
Through patterns, the learners can rehearse correct spelling, discover new as well as use familiar vocabulary, practice specific language structures such as phrases, word order, and verb tense, to name a few examples. These can be done by means of interactive and rewarding drills focusing on a particular aspect of grammar or syntax developing students' awareness of structure and phrase at the same time. This is particularly important as the two constitute a real hardship for FL learners, Polish grammar patterns being considered especially difficult.

\section{Language Problems Experienced by Users of Polish as a FL}

The most frequent language difficulties non-native speakers of Polish suffer from are morpho-syntactic in character, and Wysocka (2007) classifies them into the following:

- prepositions, for example, *Kupię na pani kawę, *Idę do poczty.

- pronouns, for example, *Tamte mężczyźni, *Widzę się z ją.

- case, for example, *Ona ma duży pies, *Potrzebuje krzesto.

- word order, for example, *Bardzo podoba sie mi, *To jest kot gruby.

- tense, for example, *Tomek wczoraj oglada film.

- aspect, for example, *Będę napisać, *Jutro ona będzie kupić ksiażkę.

- verb inflections, for example, *bylimy, *jestemy.

- verb conjugation, for example, *kupowuje, *gotowywać.

- adjective comparison, for example, *bardziej lepszy, *bliżejszy, *zdrowiejszy.

- plural forms, for example, *czlowieki, *dziecka, *studenty, *profesory.

- collocations, for example, *robić sport, *wziąć zdjęcie, *mieć prysznic.

- prefixes, for example, *przyprać pranie.

- suffixes, for example, *inteligentność.

- spelling, for example, lack of discrimination between the words kość and kosić.

In trying to find the reasons for a high frequency the above-enumerated are characterised by in the case of the Polish language, Wysocka (2007) claims that it is L1-L2 distance and disparities that give rise to language problems of that kind. For example, Chinese learners divide words into syllables in accordance with their L1 tones, or form interrogatives placing question words at the end of utterances, it being a Chinese rule of question formation. L1 habits are also visible in linguistic behaviours of English- or German-speaking students in terms of prepositions, pronouns or word order, due to ambiguities their mother tongues are allowed in the case of the first two, and a more fixed nature of the third one in comparison to Polish. The situations in which the motherese is 
devoid of the category of case (e.g., Norwegian), tense or verb inflections (e.g., Chinese), translate into inaccuracies in all these language spheres. Problems with aspect are typical of Germans learning Polish and result from the lack of equivalents to the German pluperfect in Polish. The lack of Polish correspondences is also true of verb conjugation and plurality in Japanese. The former takes on the shape of a consonant and vowel form non-existing for Poles, whereas the latter as such does not exist in Japanese at all. Difficulties with pre- and suffixation are numerous in the case of English speakers of Polish and can be boiled down to a variety of means of word formation in Polish. In final, problems with collocating words or spelling reflect circumstances under which L1-specific features influence TL performance and result in Polish forms based on and built of non-existent features regardless of L1.

More recently, Krawczuk (2008), Dilna (2008) or Dąbrowska and Pasieka (2008) add to the above-mentioned:

- government,

- grammatically-oriented phraseology, as well as

- semantic and syntactic combinability.

To start with, problems with government most often derive from L1 interferences and range from Germanic and Romanian to Slavonic languages. To name a few examples, native speakers of English would say *spędzamy mniej swojego czasu $n a$, Czechs *byłem z niej nie tylko rozczarowany and Ukrainians *tolerancja do kogoś or *Mieszkam blisko od uniwersytetu on account of apparently close, though incorrect solutions the languages suggest (Krawczuk, 2008). When it comes to phraseology, what the students struggle with is modifications of the original constructs (e.g., owijać $w$ bawetne changed into owijanie) which, as Dilna (2008) claims, unable their recognition, or, to quote Dąbrowska and Pasieka (2008) are responsible for failures at realization of phrasal verbs per se (e.g., *To byt prezent zapierajacy dech ludziom or *z wyrażeniami szacunku). Finally, problems with word and sentence relations stem from inappropriate accommodation (Markiewicz-Pławecka, 2008). This consists in wrong combinations of modifiers and words or phrases modified, resulting in such expressions as *Po świętach połowa narodu otrzyma trudności z trawieniem or *Brno jest drugie największe miasto. Surprisingly, it is Slavic learners of Polish, Bulgarians in particular, who experience difficulties with modification most frequently.

Not only do inaccurate language forms constitute frequent language problems, but also disfluencies occur in large numbers and are wide in scope. Wysocka (2007) groups them as follows:

- filled pauses, for example, Eeeee..., Aaaaa...,

- unfilled pauses,

- incorrect fixed expressions, for example, dzień dobry instead of dobry wieczór and vice versa, 
- L1 use, for example, *Bardzo sympatyczny animal, *Ten Nachtklub,

- reformulations, for example, To jest... to sq...,

- correctly formed fixed expressions, for example, Wedtug mnie...,

- reliance on English, for example, let's say..., I think..., right...,

- problems with register and style, for example, ${ }^{*} C z y$ Pani idziesz do sklepu? The first four types of behaviours seem to be equally L1-induced. To start with filled pauses the learners of Polish use, Eeee is typical of Chinese learners and users whereas Aaaa illustrative of English influences. The interchangeability of greetings under discussion is symptomatic of the French misguided by an adjective taking an initial position in bon jour. In a similar vein, the inclusion of English words is a tendency the English learners and users of Polish indicate, while German linguistic features constitute what Germans usually relate to. The remaining categories are common to all non-native speakers of Polish as a FL, irrespective of language background and source language they operate on. Paraphrasing, or an overuse of certain routine formulas, is observed whenever the learners come across obstacles in expressing themselves. Such difficulties are also resolved by means of referring to English which, being a lingua franca, serves the role of a "walking stick," regardless of other languages acquired and/ or learned. Discourse problems, to build on Dąbrowska and Pasieka (2008) are frequently the result of syllepsis, namely, a combination of semantically distant words (e.g., *odczuwają potrzebę $w$ jedzeniu, opieki i miłości) or a mixed register accounted for differences in the realization of Polish polite forms in the Slovak or Ukrainian language, to name a few (Nowakowska, 2008).

Language behaviours resulting from the reverse situation, notably, Polish playing a role of the TL, seem to be influenced by the same mechanisms influenced mostly by grammatical and morphological interferences, and reflect the following (Wysocka, 2009):

- case,

- subject-verb agreement, and

- inflection.

Providing examples from the literature, problems with case stem from fixed rules of a noun declension system in Polish and previously-mentioned nonexistence and/or its different realization in the first language as in English or Russian where the former operates on the genitive only whereas the latter relies on six when contrasted with seven in Polish (Wysocka, 2007). The resultative forms range from *Nie stuchaliśmy muzyke or *Oddaj to Adam (Korol, 2008). Likewise, subject-verb agreement tends to be troublesome for foreign learners of Polish because of a fixed verb conjugation only partially realized in for example English verb system. The case of inflection, on the other hand, imposes on Korean speakers the linguistic behaviours they cannot translate from their mother tongue. As a result, they produce such inaccuracies as ${ }^{*} C z a s$ bardzo szybko minęła or *Zjadłam dużo czekoladów (Mielczarek \& Lisowski, 2008). 


\section{The Research Proper: Problems with Grammar}

What grammatical (in)accuracies and (dis)fluencies reappear while using Polish (in speaking and writing) has been the core objective of the study conducted among the advanced users of Polish as a FL.

\section{The Sample}

The sample constituted 146 students of the Polish Language Course attending the School of Polish Language and Culture at the University of Silesia in Katowice, Poland. Eight different nationalities and languages the sample represented allowed for presenting them under the label of three different branches of the Indo-European language family, namely Germanic, Slavonic, and Romance. The first group (A) comprised 13 German (G), 16 Scandinavian (S), and 13 English (E) students of Polish as a FL, it being 46 altogether. The second (B) was composed of 24 Ukrainians (U) and 25 Slovaks (Sl.), which makes 49 in total, whereas the third group (C) consisted of 14 Italian (I), 18 Spanish (Sp.), and 19 French (F) course participants, that is 51 as a whole. As far as gender and age distribution are concerned, group A was made up of 17 female and 29 male students aged 21-45, group B contained 21 females and 28 males between 24 and 49 years of age, while in group $\mathrm{C}$ the number of female representatives came to 25 and male ones to 26 between the ages of 20 and 31. In terms of qualifications, groups $\mathrm{A}$ and $\mathrm{B}$ seemed homogeneous and included similar proportions of BA and MA degree holders, that is, 25 vs. 21 and 25 vs. 24 respondents respectively. Groups C, being younger in general, predominated in BA students (27), it being 10 more than MA students (17), as well as 7 subjects with no diplomas whatsoever. When it comes to their language experience, it was not limited to studying Polish as $100 \%$ of the German, English, Italian, Spanish, and French respondents admitted working as lecturers and/or teachers of their native language in language schools in Poland; 9, $10,4,7$, and 10 of them respectively having their BA in language and culture (teaching).

\section{Tools}

Text samples, which constituted the main source of the language material produced by the sample selected (146 respondents altogether), were divided into oral and written assignments. In both cases, the tasks the questioned subjects were confronted with covered a topic for discussion randomly chosen from a list 
of 100 quotations singled out for the purposes of the study.To give an example, the very list contained the following:

Co my wiemy, to tylko kropelka. Czego nie wiemy, to cały ocean. Isaac Newton

Twórczość to umiejętność nowego spojrzenia na starą wiedzę.

Anonim

Drzewa i kamienie nauczą cię rzeczy, których nie usłyszysz z ust żadnego nauczyciela. Św. Bernard z Clairvaux Być inteligentnym to bardzo męczące.

To, co szkodzi, uczy.

Henri Bergson

Fedrus

Nauka jest sprawą wielkich. Maluczkim dostają się nauczki.

Stanisław Jerzy Lec

As regards oral assignments, they focused on students' oral performance and were designed to record samples of the language output produced by the informants in the course of speaking. More specifically, the respondents were required to comment on one of the statements drawn from the list of quotations given. Each time, the responses recorded were intended to mirror the students' 3-minute spontaneous reactions to the topic.

As opposed to oral assignments, written tasks were focused upon examining a written discourse produced by the group under investigation. This time, each of the questioned students was asked to pick a slip of paper containing a topic for discussion. Having selected one of the quotations at a time, they were requested to remark on the issues in focus in writing, given a 30-minute time-limit.

What was looked for in students' spoken and written text samples in terms of grammar inaccuracies ranged from single words (e.g., parts of speech such as verbs, adjectives, pronouns, etc.) to phrases, clauses and sentences, including the way they are combined, positioned as well as realized in the overall language system.

\section{The Results}

When it comes to speaking, the students' performance violated rules of grammar mainly as a result of unfortunate choice and usage of language within the scope of previously-mentioned grammar patterns, structures and orientations ranging from a dozen to even a few hundred examples of a given violation (Table 3): 
Table 3.

Problems with grammar (speaking)

\begin{tabular}{|l|r|r|r|r|r|r|r|r|}
\hline \multirow{2}{*}{ Grammar problem } & \multicolumn{7}{|c|}{ Frequency of occurrence } \\
\cline { 2 - 10 } & G & S & E & U & SI. & I & Sp. & F \\
\hline Subject overuse & 92 & 100 & 125 & 72 & 88 & 99 & 108 & 100 \\
\hline Lack of subject-verb agreement & 97 & 108 & 95 & 95 & 95 & 100 & 95 & 95 \\
\hline Problems with case & 77 & 69 & 76 & 67 & 71 & 71 & 72 & 68 \\
\hline Wrong prepositions & 69 & 69 & 71 & 67 & 71 & 71 & 72 & 68 \\
\hline Problems with comparison & 62 & 63 & 65 & 63 & 64 & 64 & 67 & 63 \\
\hline Misuse of pronouns & 51 & 50 & 48 & 45 & 43 & 61 & 58 & 56 \\
\hline Problems with relative pronouns & 37 & 31 & 38 & 31 & 34 & 35 & 31 & 30 \\
\hline Verb omission & 11 & 14 & 19 & 19 & 21 & 21 & 14 & 12 \\
\hline
\end{tabular}

Qualitatively speaking, on the other hand, what the students arrived at covered the following utterances:

*Ja myślę, że ja wygram ten mecz,

*Dzieci byli z nami na zawsze,

*On kupuje jego samochody,

*Ja się cieszę do ich przyjazdu,

*Byłoby bardzo przyjemniej tam być,

*Chcę ciebie powiedzieć,

*To jest droga, na która poznasz kilka ciekawych ludzi,

*To nie podniecające

*Zapytam jemu, zapytam jemu, czy jest chętny...

*To jest tak, bo dziewczyny byli, dziewczyny byli...

All in all, the grammatical symptoms as such testified to insignificant differences between the sample, the most significant of which appeared in line with the subject overuse occurrences. What should be paid attention to, however, is the type of influences determining the form of behaviours in question. Here, the most invasive seemed English and German impact, especially when it comes to the use of wrong pronouns, relative pronouns included.

Apart from that, the students' utterances reflected a number of disfluencies. These, by definition, are caused by pauses, all-purpose words, repetitions, reformulations, unfinished utterances, over-reliance on certain structures, redundant categories or meaningless expressions, and, depending on the language feature produced, can be either erroneous or non-erroneous.

Language disfluency that accompanied grammar inaccuracy while speaking covered four different categories (Table 4): 
Table 4.

Language disfluency (speaking)

\begin{tabular}{|l|r|c|c|c|c|c|c|c|}
\hline \multirow{2}{*}{ Language disfluency } & \multicolumn{7}{|c|}{ Frequency of occurrence } \\
\cline { 2 - 11 } & G & S & E & U & SI. & I & Sp. & F \\
\hline Pauses & 177 & 113 & 200 & 300 & 180 & 60 & 70 & 70 \\
\hline Repetitions & 110 & 150 & 170 & 301 & 149 & 192 & 183 & 115 \\
\hline $\begin{array}{l}\text { Overuse of grammatically-based } \\
\text { fixed expressions }\end{array}$ & 66 & 104 & 190 & 201 & 179 & 159 & 102 & 109 \\
\hline Unfinished words/phrases & 34 & 46 & 70 & 91 & 99 & 100 & 49 & 31 \\
\hline
\end{tabular}

As the numbers show, Ukrainians were the least fluent among the participants in question, pausing, hesitating, and repeating themselves almost ad infinitum. Second "best" appeared the English-speaking students overrelying on pauses and fixed language strings, slightly taking over the Slavs and Italians who turned out to be too repetitive and linguistically fixed, as well as overused fixed expressions, and often did not care to finish their sentence.

The students' writing samples, in comparison to speaking, were more diversified and broader in scope in terms of language areas misused and/or misfitted (Table 5):

Table 5.

Problems with grammar (writing)

\begin{tabular}{|l|c|c|c|c|c|c|c|c|}
\hline \multirow{2}{*}{\multicolumn{1}{|c|}{ Grammar problem }} & \multicolumn{7}{|c|}{ Frequency of occurrence } \\
\cline { 2 - 10 } & G & S & E & U & SI. & I & Sp. & F \\
\hline Subject overuse & 90 & 96 & 114 & 69 & 81 & 96 & 105 & 99 \\
\hline Lack of subject-verb agreement & 90 & 96 & 95 & 80 & 89 & 90 & 93 & 87 \\
\hline Problems with case & 75 & 70 & 75 & 66 & 65 & 70 & 70 & 70 \\
\hline Wrong prepositions & 60 & 76 & 73 & 66 & 70 & 69 & 72 & 69 \\
\hline Wrong pronouns & 32 & 39 & 59 & 31 & 59 & 49 & 40 & 41 \\
\hline Problems with relative pronouns & 21 & 26 & 30 & 19 & 21 & 31 & 29 & 28 \\
\hline Problems with comparison & 19 & 24 & 31 & 19 & 18 & 28 & 29 & 21 \\
\hline
\end{tabular}

The numbers translated into the quality of expression, giving rise to the following utterances:

*Ja wiem, że ja...

*To jest dzień który ja lubię.

*One byli gorsze,

*Często jest tak $z$ takich sytuacjach, 
*To jest nich inicjatywa,

*Mój sąsiad, które ja gram szachy,

*Ja jestem bardzo lepszy z gramatyki

*Ja siedzę na publiczności,

*Ja mam czuć, że Polska wygra.

Following the "grammatical numbers," Ukrainian and Slovak students seemed to be the least fossilized representatives of the sample, having the biggest problems with the subject-verb concord. The weakest, on the other hand, were English- and Spanish-speaking subjects, facing all types of grammatical problems.

What was observed in line with grammatically-incorrect sentences reflected overuse of grammatically-based fixed expressions making the written text incoherent (Table 6):

Table 6.

Text incoherence (writing)

\begin{tabular}{|l|c|c|c|c|c|c|c|c|}
\hline \multirow{2}{*}{ Text-incoherence } & \multicolumn{7}{|c|}{ Frequency of occurrence } \\
\cline { 2 - 9 } & G & S & E & U & SI. & I & Sp. & F \\
\hline $\begin{array}{l}\text { Overuse of grammatically-based } \\
\text { fixed expressions }\end{array}$ & 19 & 27 & 59 & 71 & 45 & 99 & 76 & 40 \\
\hline
\end{tabular}

As seen from the table, these ranged from several to almost one hundred of occurrences. Irrespective of observable frequency, though, the language produced was deprived of its factual quality most frequently in the case of Italians or Spaniards who seemed to celebrate the very fact of just expressing themselves, and writing as such, rather than conveying the message. The representatives of the remaining nationalities produced shorter text samples so a lower number of fixed expressions reappearing while writing may be the result of such a situation.

\section{Ways of Overcoming Problems}

In trying to avoid and/or overcome at least some of the above-listed difficulties, one should neither understate nor undermine the power and benefits of language practice, be it the classroom or (home) work. 


\section{Using Poetry}

The examples of assignments presented below, though cater for only some problems listed above, differ from the tasks included in traditional course books as they are based on poetry. They are believed to not only broaden the perspective of problem recovery, but also language mastery, developing linguistic competence and reflection on language at the same time irrespective of the course or study attended. The poems in question are written by the author of the article, and offer a remedial work on a language, in the form of a recognition/production task (see Table 7).

Table 7.

TASK 1 (Poem taken from Wysocka, 2010, p. 49)

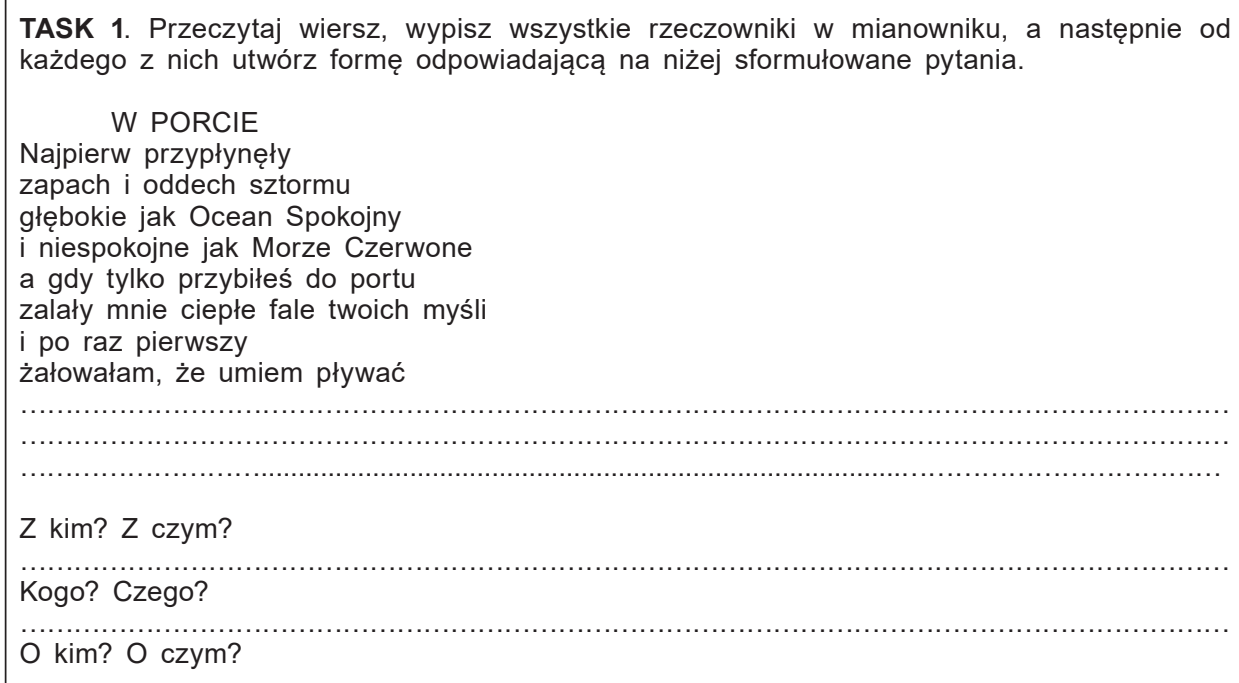

Here, it is the case of nouns that the learners are confronted with. First, they are asked to write down all the nouns in the nominative case, and then proceed to answering a few questions, each reflecting a different case in Polish.

A more demanding exercise, on the other hand, is threefold. It opens with a part devoted to all the adjectives presented in the text. What follows concerns the way the very adjectives should be matched with nouns given leaving the original forms unchanged. And, finally, sentences are to be created on the basis of previously-coined adjective + noun combinations (see Table 8). 
Table 8.

TASK 2 (Poem taken from Wysocka, 2010, p.28)

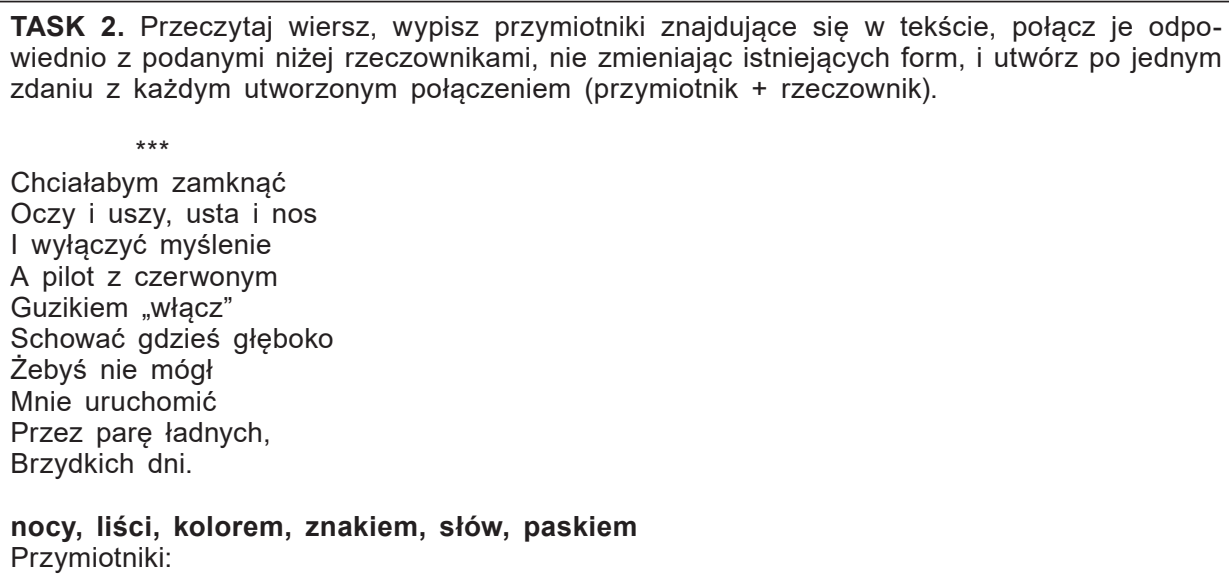
wiednio $z$ podanymi niżej rzeczownikami, nie zmieniając istniejących form, i utwórz po jednym zdaniu z każdym utworzonym połączeniem (przymiotnik + rzeczownik).

Chciałabym zamknąc

Oczy i uszy, usta i nos

I wyłączyć myślenie

A pilot z czerwonym

Guzikiem "włącz"

Schować gdzieś głęboko

Żebyś nie mógł

Mnie uruchomić

Przez parę ładnych,

Brzydkich dni.

nocy, liści, kolorem, znakiem, słów, paskiem

Przymiotniki:

Przymiotniki z rzeczownikami:

Zdania:

\section{Conclusions}

The suggestion is to use poetry-based exercises for any language area(s) the students have problems with or are not confident about, and, thus, influence their language awareness; its attention, noticing and understanding components.

Irrespective of the type of a poetic text, using poetry in a FL classroom is believed to help understand relationships in meaning between words, while a stylistic analysis of poems is likely to improve learners' understanding of discourse, an emphasis being put on developing inference-making skills.

The future research could further explore the students' linguistic competence, be it lexis, morphology, phonology, spelling and/or punctuation. Having investigated the students' problems within a given language area, a series of poetic texts could be implemented depending on the group and its needs. Ideally, they could serve as a remedy for something that still goes wrong or as a positive reinforcement to encourage and reward proper linguistic behaviours. 
Secondly, the research may be additionally equipped with a questionnaire aimed at collecting learners' opinions on using poetry as a way of polishing the language in the classroom context.

\section{References}

Burzyńska, A., \& Markowski, M. P. (2006). Teorie literatury XX wieku. Podręcznik. Kraków: Znak.

Cadorath, J., \& Harris, S. (1998). Unplanned classroom language and teacher training. ELT Journal, 52(3), 188-196.

Carter, R., \& Long, M. (1991). Teaching literature. London: Longman Group.

Dąbrowska, A., \& Pasieka, M. (2008). Błędy językowe w tekstach pisanych przez cudzoziemców - wybrane problem związane z klasyfikacją i oceną. In A. Seretny \& E. Lipińska, (Eds.), Rozwijanie i testowanie biegłości w języku polskim jako obcym (pp. 103-113). Kraków: Universitas.

Dilna, J. (2008). Frazeologizmy w polskiej prozie młodzieżowej. Problemy z recepcją odbiorcy ukraińskiego uczącego się polszczyzny. In A. Seretny \& W. T. Miodunka, (Eds.), W poszukiwaniu nowych rozwiazań. Dydaktyka języka polskiego jako obcego u progu XXI wieku (pp. 131-149). Kraków: Wydawnictwo Uniwersytetu Jagiellońskiego.

Franceschina, F. (2005). Fossilised second language grammars: The acquisition of grammatical gender. Amsterdam: John Benjamins.

Finch, A. (2003). Using poems to teach English. English Language Teaching, 15, 29-45.

Hadfield, C., \& Hadfield, J. (1997). Writing games. Harlow: Longman,

Han, Z.-H. (2004). Fossilization in adult second language acquisition. Clevedon, England: Multilingual Matters.

Hanauer, D. I. (2001). Focus-on-cultural understanding: Literary reading in the second language classroom, Cauce. Revista de Filología y su Didáctica, 24, 389-404. Retrieved from: http:// cvc.cervantes.es/literatura/cauce/pdf/cauce24/cauce24_23.pdf

Holmes, V. L., \& Moulton, M. R. (2001). Writing simple poems: Pattern poetry for language acquisition. Cambridge: Cambridge University Press.

Korol, Ł. (2008). Odstępstwa od normy gramatycznej w polszczyźnie młodzieży polskich szkół Lwowa i studentów polonistyki lwowskiej. In A. Seretny \& W. T. Miodunka (Eds.), W poszukiwaniu nowych rozwiazań. Dydaktyka języka polskiego jako obcego u progu XXI wieku W poszukiwaniu nowych rozwiąań (pp. 199-213). Kraków: Wydawnictwo Uniwersytetu Jagiellońskiego.

Kozłowski, A. (1991). Literatura piękna w nauczaniu języków obcych. Warszawa: WSiP.

Krawczuk, A. (2008). Nauczanie Ukraińców polskiej etykiety językowej (zwracanie się do adresata). In A. Seretny \& W. T. Miodunka (Eds.), W poszukiwaniu nowych rozwiazań. Dydaktyka języka polskiego jako obcego u progu XXI wieku (pp. 301-311). Kraków: Wydawnictwo Uniwersytetu Jagiellońskiego.

Kryżan-Stanejović, B. (2008). Dyktando jako sprawdzian ogólnej kompetencji językowej. In A. Seretny \& E. Lipińska (Eds.), Rozwijanie i testowanie biegłości w języku polskim jako obcym (pp. 71-80). Kraków: Universitas.

Lewis, M. (1986). The English verb. An exploration of structure and meaning. Hove: LTP. 
Long, M. (2003). Stabilization and fossilization in interlanguage development. In C. Doughty \& M. Long (Eds.), Handbook of Second Language Acquisition (pp. 487-536). Oxford: Blackwell.

Magajewska, M. (2008). Problemy fonetyczne Włochów uczących się języka polskiego - ujęcie porównawcze. In A. Seretny \& W. T. Miodunka (Eds.), W poszukiwaniu nowych rozwiazań. Dydaktyka języka polskiego jako obcego u progu XXI wieku (pp. 185-311). Kraków: Wydawnictwo Uniwersytetu Jagiellońskiego.

Majtczak, T., Sieradzka-Baziur, B. (2008). Interferencja w procesie przyswajania języka polskiego przez Japończyków. In A. Seretny \& W. T. Miodunka (Eds.), $W$ poszukiwaniu nowych rozwiązań. Dydaktyka języka polskiego jako obcego u progu XXI wieku (pp. 185204). Kraków: Wydawnictwo Uniwersytetu Jagiellońskiego.

Markiewicz-Pławecka, B. (2008). Błędy w łączliwości składniowej w tekstach pisanych przez Słowian znających język polski na poziomie zaawansowanym. In A. Seretny \& and E. Lipińska (Eds.), Rozwijanie i testowanie biegłości w języku polskim jako obcym (pp. 115-128). Kraków: Universitas.

Mielczarek, A., \& Lisowski, T. (2008). Typologia błędów fleksyjnych Koreańczyków uczących się języka polskiego. In A. Seretny \& W. T. Miodunka (Eds.), W poszukiwaniu nowych rozwiąań. Dydaktyka języka polskiego jako obcego u progu XXI wieku. W poszukiwaniu nowych rozwiązań (pp. 159-168). Kraków: Wydawnictwo Uniwersytetu Jagiellońskiego.

Mrożek, E. (1999). W “tajemniczym ogrodzie” poezji (propozycja warsztatowa). In G. Teusz \& B. D. Gołębniak (Eds.), Edukacja poprzez język: o całościowym uczeniu się (pp. 120-134). Warszawa: Wydawnictwa CODN.

Nowakowska, M. M. (2008). Językowy savoir-vivre: nauczanie polskich form grzecznościowych na gruncie słowackim. In A. Seretny \& W. T. Miodunka (Eds.), W poszukiwaniu nowych rozwiązań. Dydaktyka języka polskiego jako obcego u progu XXI wieku (pp. 323-335). Kraków: Wydawnictwo Uniwersytetu Jagiellońskiego.

Selinker, L. (1974). Interlanguage. In J. C. Richards (Ed.), Error analysis (pp. 31-54). London: Longman.

Selinker, L. 1992. Rediscovering interlanguage. London: Longman.

Selinker, L., \& Lakshmanan, U. (1993). Language transfer and fossilization. In S. M. Gass \& L. Selinker (Eds.), Language transfer in language learning (pp. 197-221). Amsterdam: John Benjamins.

Selinker, L., \& Han, Z-H. (1996). Fossilization: What do we think we know? Paper presented at EUROSLA 6, Nijmegen.

Szczęśniak, D. (2009). Środki retoryczne, liryka, glottodydaktyka - o zastosowaniu poezji na lekcji języka obcego. Neofilolog 33, 157-165.

Thornbury, S. (1999). How to teach grammar. Harlow: Longman.

Wierzbicka, A. (2001). Kultura języka polskiego. Praktyczne ćwiczenia. Łódź: Wydawnictwo Wyższej Szkoły Humanistyczno-Ekonomicznej.

Willis, D. (2005). Rules, patterns and words. Grammar and lexis in English language teaching. Cambridge: Cambridge University Press.

Wysocka, M. S. (2007). Język polski językiem obcym. O problemach językowych wśród uczących się języka polskiego jako języka obcego. Języki Obce w Szkole, 2, 162-164.

Wysocka, M. S. (2009). Stages of fossilization in advanced learners and users of English: A longitudinal diagnostic study. Częstochowa: Wydawnictwo Wyższej Szkoły Lingwistycznej.

Wysocka, M. S. (2010). Nie tylko we śnie. Jastrzębie Zdrój: Wydawnictwo BLACK UNICORN. Wysocka, M. S. (2012). Tylko tyle. Jastrzębie Zdrój: Wydawnictwo BLACK UNICORN. 